\title{
An Analysis of the Change in the Attitudes and Behaviors of Users before and after the Pandemic: Case Study; Ankara Çubuk-1 Dam ${ }^{\#}$
}

\author{
Sertaç Güngör ${ }^{1, a, *}$, Elif Nur Doğan ${ }^{2, b}$ \\ ${ }^{1}$ Department of Landscape Architecture, Faculty of Architecture and Design, Selçuk University, 42250 Selçuklu/Konya, Turkey \\ ${ }^{2}$ Department of Landscape Architecture, Institute of Science and Technology, Selcuk University, 42250 Selçuklu/Konya, Turkey
} *Corresponding author

\begin{tabular}{|c|c|}
\hline A R T I C LE I NFO & A B S T R A C T \\
\hline $\begin{array}{l}{ }^{\#} \text { This study was presented as an } \\
\text { online presentation at the } 2^{\text {nd }} \\
\text { International Journal of Agriculture - } \\
\text { Food Science and Technology } \\
\text { (TURJAF 2021) Gazimağusa/Cyprus } \\
\text { Research Article } \\
\text { Received : 17/11/2021 } \\
\text { Accepted : 24/12/2021 } \\
\text { Keywords: } \\
\text { Covid-19 } \\
\text { Coronavirus } \\
\text { Pandemic } \\
\text { Recreation } \\
\text { Green Area }\end{array}$ & $\begin{array}{l}\text { During the pandemic process that has been going on for more than a year since the pandemic period } \\
\text { was declared in } 2020 \text {, the troubles and restrictions faced by people negatively affect the morale } \\
\text { motivation of people. In this study, the definition of recreation areas, which are the leading places } \\
\text { where people feel happy and peaceful, has been defined, what they contain is mentioned, and the } \\
\text { adequacy of the recreational areas has been discussed in the survey and it has been determined that } \\
\text { they are one of the most important needs in the cities. In the example of the recreation area of Çbuk- } \\
1 \text { dam, it was investigated whether there is a change in the attitudes and behaviors of people before } \\
\text { and after the pandemic, not face to face due to the pandemic, but through a voluntary survey based } \\
\text { on social media. Although individuals thought that it was crowded after the pandemic, they preferred } \\
\text { to use the recreation area of Çubuk-1 dam by paying attention to mask, distance and hygiene rules. } \\
\text { The positive effects of physical activity, socialization, and outdoor travel on health are generally } \\
\text { accepted by individuals. During the pandemic process, it has been observed that people have changed } \\
\text { the way they spend their free time and the places they want to be, as they are overwhelmed by staying } \\
\text { in their homes due to the prohibitions. The psychological and physical positive effects of recreation } \\
\text { areas on human health and the changes caused by the pandemic in people's attitudes and behaviors } \\
\text { paralleled the responses of the participants to the questionnaire. }\end{array}$ \\
\hline
\end{tabular}

Türk Tarım - Gıda Bilim ve Teknoloji Dergisi, 9(sp): 2466-2473, 2021

\section{Kullanıcıların Pandemi Öncesi ve Sonrası Tutum ve Davranışlarındaki Değişimin Ankara Çubuk-1 Barajı Örneğinde İncelenmesi}

\begin{tabular}{|c|c|}
\hline M A K A L E B İ L G İ S İ & Ö Z \\
\hline $\begin{array}{l}\text { Anahtar Kelimeler: } \\
\text { Covid-19 } \\
\text { Koronavirüs } \\
\text { Pandemi } \\
\text { Rekreasyon } \\
\text { Yeşil alan }\end{array}$ & $\begin{array}{l}2020 \text { yılında pandemi döneminin ilan edilmesinden bu yana bir yılı aşkın süredir devam etmekte olan } \\
\text { pandemi sürecince insanların yaşadığı sıkıntılar ve karşılaştığı kısıtlamalar insanların moral } \\
\text { motivasyonunu olumsuz etkilemektedir. Bu araştırmada insanların kendilerini mutlu ve huzurlu } \\
\text { hissettiği yerlerin başında gelen rekreasyon alanlarının tanımı yapılmış, neler içerdiğinden } \\
\text { bahsedilmiş ve yapılan ankette rekreasyon alanlarının yeterliliği tartışılmış ve elde edilen sonuçlardan } \\
\text { kentlerdeki en önemli ihtiyaçlardan biri olduğu tespit edilmiştir. Çubuk-1 barajı rekreasyon alanı } \\
\text { örneğinde, pandemi öncesi ve sonrası kişilerin tutum ve davranışlarında değişiklik olup olmadığı } \\
\text { pandemi nedeniyle yüz yüze olarak değil de sosyal medya üzerinden yapılan, gönüllülük esasına } \\
\text { dayanan anket ile araştırılmıştır. Bireyler pandemi sonrasında kalabalık olduğunu düşünmelerine } \\
\text { rağmen maske, mesafe ve hijyen kurallarına dikkat ederek Çubuk-1 barajı rekreasyon alanını } \\
\text { kullanmayı tercih etmişlerdir. Fiziksel aktivite yapmanın, sosyalleşmenin, açık havada gezmenin } \\
\text { sağlığa olan olumlu etkisi bireyler tarafindan genel kabul görmektedir. Pandemi sürecinde } \\
\text { yasaklardan dolayı insanlar evlerinde kapalı kalarak bunaldıkları için, boş zamanlarını geçirme } \\
\text { şekillerini ve bulunmak istedikleri mekanları değiştirdikleri görülmüştür. Rekreasyon alanlarının } \\
\text { insan sağlığı üzerindeki psikolojik ve fiziksel olarak olumlu etkisi ve pandeminin kişilerin tutum ve } \\
\text { davranışlarında meydana getirdiği değişiklikler, katılımcıların ankete verdiği cevaplarla paralellik } \\
\text { göstermiştir. }\end{array}$ \\
\hline
\end{tabular}




\section{Introduction}

In all stages of history pandemics, affecting public health negatively, have always existed. Crowded and close-knit lifestyle in cities has unfortunately resulted in a close contact among dwellers consequently leading to substructure problems and outbreak of pandemics (Erdoğanaras et al., 2020). In addition; global warming, unplanned urbanization, destruction and unwise use of natural resources, mistakes in settlement-place selection that were triggered by neoliberal urbanization policies have also been adversely affecting the surge in pandemic (Karlı and Çelikyay, 2020).

On the night of December 30, 2019 Health Commission of Wuhan Municipality issued a letter on pandemic which took all the world by surprise and soon after, the news were circulated on social media. On December 31, Wuhan Press confirmed the prevalence of an unidentified disease (Anonim 2020). Reported pneumonia-like patients that gained attention in Wuhan city of China on December 31, 2019 alarmed World Health Organization. On January 7, 2020 official authorities in China declared the outbreak of a novel Corona Virus causing pneumonia and at the first stage, the outbreak was named as 2019-nCoV (Tunçay and Eşbah, 2020). As a result of the researches among patients displaying respiratory signs (fever, cough, asthma) the disease was thoroughly described on January 13, 2020. Whole world began to investigate viral features, the way this virus spread and the most hit-hard group by this virus and focused on finding the right treatment solutions (Anonim, 2020b).

March 11, 2020 dated official statement by the World Health Organization (WHO) declared COVID-19 outbreak a global pandemic (Anonim, 2020b).

The first case of the global COVID-19 outbreak in Turkey was confirmed by the Ministry of Health on March 10, 2020. First death was registered on March 15, 2020 and Minister of Health, Fahrettin Koca, on his April 1, 2020 dated press meeting announced the spread of new cases all over Turkey (Anonymous, 2020). Upon this news, restrictive measures became the new norm of life all over the nation and limitations were enacted in various areas of daily life.

In Turkey the first measure taken during pandemic situation was designed by Science Committee. Next, as of February, all international flights were installed with thermal cameras. Later some border gates were closed, travelers from abroad were quarantined. In public places such as hairdressers, barbers, cafes and restaurants closures were enforced. As of the first case recorded on March 11, 2020 schools were closed step by step nationwide, art and sports events were paused, outdoor spaces such as parks and picnic sites were out of service, collective praying at mosques were banned, malls were temporarily closed down, citizens above age 65 and below age 20 were prohibited from leaving their home and on specific days every citizen was forced to abide by nationwide curfew. Entire country was demanded to "Stay Home" (Hepgüner and Yücel, 2021).

In addition to state-imposed measures, many citizens were willfully bound to home and tried to stay away from crowded places. More to that, a partial home-working system was administered, state institutes and private sector also began to work in shifts.

An undesired outcome of COVID-19 quarantine lockdowns is decrease in the physical activity levels of children and teenagers and increase in sedentary behaviors. Conducted scientific studies have revealed that decrease in physical activity level most negatively affect children, youngsters, teenagers, overweight or obese adults. Therefore, members of these groups experienced adverse effects in terms of mental and spiritual state in particular and a fall by $30-50 \%$ in their physical activity was reported (Hepgüner and Yücel, 2021). Adults and children and people not interacting with others due to external forces have listed a wide range of complaints such as headache, gut issues, depression precursors and physical ailments. Physiological problems observed among people during lockdowns have further accentuated the vital interlink between urban environment and health (Erdoğanaras et al., 2020).

Considering the great risk COVID-19 inflicts upon personal health, it is quite normal that studies and analyses have mostly tended to focus on certain factors such as personal risks or disposition to abide by individual restrictions (Abrams et al., 2021). Based on these factors, circles were drawn in the green areas at parks to draw the distance among people, and through this method it was aimed to allow users to socialize under certain limits. The very first models for this method emerged in New York city of the USA and in Turkey the same model was used in İstanbul Maltepe Orhangazi Park. Added to that, one of the reasons to multiply the number of green areas, which function as gathering sites in cities, is that urbanites feeling entrapped in city center and looking for an escape deeply desire to spend time by the riverside, lakeside and green places to take a rest and find some peace (Çam, 2020).

As an effect of pandemic, the gravity of green spaces having a critical value in daily life is becoming even more vital as days pass by and restrictions become further stricter. Humans can attain some psychological comfort though minimal- by maintaining interaction with their environment but it is for sure that parks and green spaces offer much greater contribution to that kind of relief (Güngör, 2019). Being forced to homebound at the lockdowns in pandemic period, citizens mostly preferred to spend time in parks and green spaces once the restrictions were loosened. However, since many people had no parks near walking distance, they simply could not enjoy the psychological state of wellness offered by park visits, and even if they did use the parks, they could hardy follow social distancing rules because of the narrow square meters of park zone. As a result, the need to expand the size of existing green spaces in cities became well understood. In green space designs after pandemic, the necessity to project the kind of areas that people could make use of personally- not in groups- became more apparent. Walking tracks should be widened, exercise zones should be redesigned as per social distancing rule, the number and size of parks should be incremented to enable easy access of the elderly and kids (Özcü and Atanur, 2020). 
Further to that according to relevant studies choosing different kinds of spaces by different age groups, experiencing social ostracization of certain disadvantageous groups due to their physical disability or age and allotting the best services by socio-economically strong groups have been among the unwanted outcomes (Erdoğanaras et al., 2020). Since urban green spaces failed to offer a fair share of service to every citizen, those living nearby green sites enjoyed the full benefits of green sites whilst the elderly, children and the disabled could not maximally utilize green spaces. Travel bans enacted in many countries and local administrative policies allowing residents to stay in their registered place only highlighted current urban planning and design challenges in cities having failed to complement their green space deficiency (Ahmadpoor and Shahab, 2021).

Psychological and social utility that humans gain in their free time outside of work-hours is defined as recreation and recreational activities are physical and spiritual actions that are conducted individually or collectively and making participants happy with no expectations for any financial gain (Bayramoğlu and Yurdakul, 2020). In this century, there are 3 factors that people keep intact while they still elevate their life standards and these are work, sleep and other needs. Making use of physical and socio-economic options in the remaining free time from work hours are named as recreational activities (Coşku and Koçyiğit, 2020). With the development in city parks and setting voluntary organizations, it was aimed to raise environmental awareness and with the establishment of 1906-dated "Playground Association of America (PAA)" recreation movement has received official recognition (Chen et al., 2020).

Recreational activities allow humans to get a full-scale physical, psychological and spiritual revival, to achieve self-development and to cope with life. To be away from stress sightseeing, entertaining, spending good time at home or outside in and around the city are named as freetime recreational activities. Physical activities that can render physical, spiritual and mental wellness are the kind of activities which can be performed outdoors (Loureiro and Veloso, 2014). In another saying they are the kind of free-time activities encompassing various movements like sports, theater, museum and movie visits (Coşku and Koçyiğit, 2020).

As a result of the time we spent at home due to pandemic measures, there is a corresponding rise in the demand for recreational activities. In line with their demands people began to search for appropriate places. Because of the potential of certain communicable diseases, even before the pandemic outbreak, outdoor spaces in neighborhood scale were still important but in pandemic period they gained even more value. So much so that some of the streets were closed to let children ride their bikes safely (Erdoğanaras et al., 2020). To stay away from negative factors around and to relax and improve themselves people have been in need of recreational activities. In an attempt to complement their spiritual downsides, people have visited in their free time recreation areas with no financial-gain expectations (Bayramoğlu and Yurdakul, 2020). Outdoor physical activities affect humans' feelings and health positively and help them focus better and relevant studies also showed that outdoor physical activities can influence our mood positively (Loureiro and Veloso, 2014).

Outdoor recreation relates to the kind of activities allowing people to connect with nature. In another saying, they are physical and mental activities helping people to relieve the stress of modern city life (Eryilmaz and Kamil, 2019). Outdoor recreational activities grant the freedom of movement and allow people to be actively present in nature. They infuse the kind of personality traits such as acting collectively, leadership and finding solutions to the community and individuals (Coşku and Koçyiğit, 2020). In relation to the value recreation sites add to cities, the use and distribution of these sites should be attentively and holistically designed by taking into account the interests of people with different socio-economic and cultural features (Coşku and Koçyiğit, 2020).

The environment designed for the society can affect public health either positively or negatively according to the means it has. Recreation demands of settlers are met by tracks, parks and walking areas in the neighborhood. Walking renders a positive effect on social relations, physical and mental health and is known as a major activity bettering life quality. Extended screen time in front of computers and TV, lack of trust among people, minimal neighborhood relations and societal breakdown force people to lead isolated lives. During pandemic situation this isolation escalated more, and deaths caused by obesity, heart problem and psychological disorders correspondingly climbed. Individuals confined in isolated communities are unable to effectively cope with crises and public health issues (Erdoğanaras et al., 2020). UN General Secretary Guterres claimed that in crowded and congested settlements, there is greater risk of Covid-19 spread and on a global scale $90 \%$ of emergent cases broke out in cities and this statement evidences that dense population in cities poses a major risk for the virus (Anonim, 2020c). Hosting a dense population, cities are in need of comprehensive recreation sites that entertain residents while also making them relax and allowing them to partake in social activities and these areas are called as city parks. These parks should be designed by assessing every recreation mean in areas fitted with natural and cultural assets. They are compound green spaces made by humans and free for everyone and these spaces allow kids to play games while dreaming and also providing a favorable setting to form positive interaction personally or collectively. Parks present all available means for active and passive recreational activities. Provided that they are well-planned, these occasionally-visited sites can allow the youngsters and children to hone their talents and enable individuals to raise their life quality (Polat et al., 2018).

That is why parks, by helping humans do regular sports, offer substantial contribution to our health. People living away from parks have lower chance for physical activity which can alleviate cardiac diseases, psychological disorders, cancer, diabetes, and lung disease. Results of international research suggest that employees working in buildings fitted with a green space have greater satisfaction level and fewer absenteeism records and higher productivity levels. Studies so far have evidenced that buildings with a green space minimize damage to nature, offer a more comfortable and healthy setting to their 
employees and consequentially a decrease in health issues (Kılıç and Güdük, 2018).

Conducted research reveal that planning and design interventions rendered for green space use can minimize the pressure on health system via rendering positive effects on society. In the aftermath of pandemic outbreak, city planners and designers are required to prioritize green space in their projects (Ahmadpoor and Shahab, 2021). By virtue of the fruitful union of green sites with mental health, humans should easily access to such green sites. Obtained findings from the study attested that looking at green spaces and spending time outdoors alleviated psychological problems and those utilizing green spaces and living much closer to green areas benefited more than those not utilizing the green. Findings indicate that these parks hold value not only in utilizing green sites and type of performed activities but also play a salient role in people's motivation to use green areas (Gascon et al., 2015).

To boost life quality, it is essential to stick to physical activities during old age too. The motives of the elderly in visiting urban outdoor sites are listed as; naturality, accessibility and safety (Düzenli and Alpak, 2017).

In another research it was reported that during pandemic situation, participants continued to use green sites and participants agreed that green sites offered great health benefits prior to pandemic outbreak too. Studies highlighted that in pandemic period, value of urban green spaces should be accentuated and in order to avoid inequality in terms of public health, easy access to such sites must be kept on during times of crisis (Lopez et al., 2020).

Opened in 1936 by Mustafa Kemal Atatürk in an attempt to overcome droughts and fires in capital city Ankara and its surrounding environment and to fulfill demand for water, Çubuk-1 Dam was opened to public use on Oct. 29, 2020 upon landscaping, repair and maintenance works completed by Ankara Metropolitan Municipality.

In this recreation site; Atatürk Mansion, flag hillpanorama slope, scripted gate, 736-meters long nature walking track, terrace cafe, concourse, single heart (Tekyürek) activity site, 520-meters long bicycle track, 219-thousand square meters picnic site, sports field, plane tree resting area, greenhouse, playground, mosque, car park and 1250 trees, 75 thousand bushes, 15 thousand flowers, 3 thousand ivies, 20 thousand square meters of grass field, 4 fountains, 3 ponds, 2 playgrounds for kids, 619-car capacity auto park, 163 picnic tables, 1 shop-cafe, 1 cafe and 1 bistro. Atatürk Mansion inside the complex was also restored according to its historical quality and opened to visitors as a space displaying photographs from the past ages (Özgen and Büyüktolu, 2016). Çubuk-1 Dam Recreation Site was transformed into an area that would fulfill recreational activity demands and expectations of metropolitan residents.

\section{Method}

In this study, at first, a large-scale literature review was conducted to unveil where and how COVID-19 broke out, the way it can be detected and transmitted, protection methods, measures, and benefits of green spaces in pandemic period. Next, to identify changes fueled by
Çubuk-1 Dam recreation site in people's attitudes before and after the pandemic, a survey on voluntary basis was applied and this survey and literature studies were collectively analyzed.

Via random sampling method, a survey was administered among 180 people: 90 female and 90 male participants. Data obtained from the survey administered to park users were designed in Excel software and statistical analyses were conducted in SPSS software. Hypothesizing that there is normal distribution, chi-square tests in $95 \%$ confidence interval were applied and were analyzed in $\alpha=0,05$ significance level.

Social media applications were harnessed as data collection tool due to weekend-curfews imposed during pandemic period. The survey was compartmented as before and after the pandemic and directives were rendered to get a better idea about preferential choices before and after the pandemic, behavior change, perspectives, and expectations.

\section{Findings}

In social media, individuals who went to Çubuk dam both before and after the pandemic were surveyed on social media using Google questionnaires. By following the changes in the tables below, the change in recreational activities in the area before and after the pandemic has been tried to be revealed.

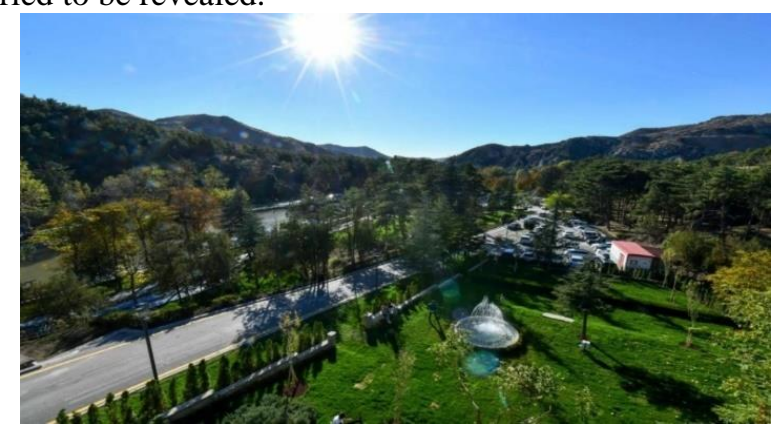

Figure 1. Ankara Çubuk-1 Dam Recreation Area (https://images.app.goo.gl/c8RLv8SmZPtamYbS7)

Table 1. Distribution of participants by age

\begin{tabular}{l|cc}
\hline \multicolumn{1}{c|}{ Age } & $\mathrm{N}$ & $\%$ \\
\hline $15-18$ & 5 & 2.8 \\
$19-25$ & 28 & 15.6 \\
$26-35$ & 57 & 31.7 \\
$36-50$ & 60 & 33.3 \\
$50-64$ & 25 & 13.9 \\
65 age and over & 5 & 2.8 \\
\hline Total & 180 & 100.0 \\
\hline
\end{tabular}

Table 2. Distribution of participants according to educational status

\begin{tabular}{l|cc}
\hline \multicolumn{1}{c|}{ Educational statu } & $\mathrm{N}$ & $\%$ \\
\hline Literate & 2 & 1.1 \\
Primary School & 9 & 5.0 \\
Middle School & 6 & 3.3 \\
High School & 50 & 27.8 \\
Associate & 33 & 18.3 \\
Licence & 55 & 30.6 \\
Graduate & 25 & 13.9 \\
\hline Total & 180 & 100.0 \\
\hline
\end{tabular}


Table 3. Distribution of participants according to Educational status

\begin{tabular}{l|cc}
\hline \multicolumn{1}{c|}{ Educational status } & $\mathrm{N}$ & $\%$ \\
\hline Officer & 63 & 35.0 \\
Small business & 9 & 5.0 \\
Employee & 46 & 25.6 \\
Housewife & 19 & 10.6 \\
Student & 16 & 8.9 \\
Farmer & 3 & 1.7 \\
Unemployed & 10 & 5.6 \\
Retired & 14 & 7.8 \\
\hline Total & 180 & 100.0 \\
\hline
\end{tabular}

Table 4. Distribution of the participants by residency:

\begin{tabular}{l|cc}
\hline & Frequency & Valid Percent \\
\hline Çubuk & 41 & 22.9 \\
Etimesgut & 29 & 16.2 \\
Keçiören & 25 & 14.0 \\
Yenimahalle & 21 & 11.7 \\
Çankaya & 13 & 7.3 \\
Altındağ & 12 & 6.7 \\
Mamak & 11 & 6.1 \\
Sincan & 11 & 6.1 \\
Diğer & 7 & 3.9 \\
Pursaklar & 5 & 2.8 \\
Akyurt & 2 & 1.1 \\
Kazan & 2 & 1.1 \\
\hline
\end{tabular}

Table 5. Response to the question: Before the pandemic did you use to visit Çubuk-1 Dam Recreation Site?

\begin{tabular}{l|cc}
\hline & Frequency & Valid Percent \\
\hline Yes & 86 & 47.8 \\
No & 94 & 52.2 \\
\hline
\end{tabular}

Demographic structure of the participants is shown using Tables 1, 2, 3 and 4. The attitudes and behaviors of the participants before and after the pandemic are also shown using Tables 5, 6, 7, 8, 9 and 10. The changes in the attitudes and behaviors of the participants in the park after the pandemic are shown using tables 11, 12, 13 and 14 .

Accordingly, it can be seen that there are visitors from not only near distance but also from remote corners and as we consider the distance of where they come from to a recreation site, it becomes apparent that users make decisions independent of distance. After the pandemic the reason for not frequently visiting was reported as the distance thus assumption in increasing the number of green spaces was also disclosed in survey responses.

In this question it was aimed to see if or not participants visited Çubuk-1 Dam recreation site before the pandemic process and it became apparent that $52,2 \%$ of those visiting Çubuk-1 Dam recreation site after the pandemic had never been in here before the outbreak. This significant percentage reminds us that due to the pandemic there is greater tendency towards visiting green spaces and this tendency is supportive of the search of humans for green areas. In addition, the response to the question we asked to the participants in order to compare pre and post pandemic period; did you use to visit Çubuk-1 Dam recreation site? posited that those not having visited before the pandemic started to visit after it broke out.

In addition, when the participants who had visited Çubuk-1 dam before the pandemic were asked about their frequency of visits; $7.1 \%$ of the participants stated that they go once a week, $4.8 \%$ twice a week, $34.5 \%$ once a month and $53.6 \%$ once a year.

Before the pandemic, frequency of visits to Çubuk-1 Dam recreation site was recorded as just one time or once in a year and this suggests that in pre-pandemic stage, this recreation site was not much popular among the visitors.

Survey results show that visitors favored Çubuk-1 Dam recreation site thanks to its peacefulness and chance to spend longer time in. Besides, nearly all visitors prefer to come with family or friends by their private car.

Table 6. Identifying attitude change of people towards Çubuk-1 Dam recreation site before and after the pandemic:

\begin{tabular}{|c|c|c|c|c|c|c|c|}
\hline \multirow{2}{*}{\multicolumn{2}{|c|}{$X^{2}<0,05$}} & \multicolumn{5}{|c|}{$\begin{array}{c}\text { Has the number of people coming to the çubuk-1 dam decreased } \\
\text { during the pandemic process? }\end{array}$} & \multirow[t]{2}{*}{ Total } \\
\hline & & Definitely yes & yes & undecided & no & Definitely no & \\
\hline Would you go to the & Yes & - & $44.2 \%$ & $29.1 \%$ & $25.6 \%$ & $1.2 \%$ & $100.0 \%$ \\
\hline çubuk-1 dam before & No & $3.3 \%$ & $25.3 \%$ & $56.0 \%$ & $13.2 \%$ & $2.2 \%$ & $100.0 \%$ \\
\hline the pandemic? & Total & $1.7 \%$ & $34.5 \%$ & $42.9 \%$ & $19.2 \%$ & $1.7 \%$ & $100.0 \%$ \\
\hline
\end{tabular}

Table 7. Visitors' use of communal sites before and after the pandemic was gauged

\begin{tabular}{|c|c|c|c|c|c|c|}
\hline & & \multicolumn{2}{|c|}{ Before pandemic $(\%)$} & \multicolumn{3}{|c|}{ After pandemic $(\%)$} \\
\hline \multicolumn{2}{|l|}{ Definitely no } & \multicolumn{2}{|l|}{3.2} & \multicolumn{3}{|c|}{8.0} \\
\hline & & \multicolumn{2}{|l|}{12.9} & \multicolumn{3}{|c|}{29.5} \\
\hline undecided & & \multicolumn{2}{|l|}{6.5} & \multicolumn{3}{|c|}{14.8} \\
\hline & & \multicolumn{2}{|l|}{74.2} & \multicolumn{3}{|c|}{45.5} \\
\hline Definitely yes & & \multicolumn{2}{|l|}{3.2} & \multicolumn{3}{|c|}{2.3} \\
\hline \multirow{2}{*}{\multicolumn{2}{|c|}{$X^{2}<0,05$}} & \multicolumn{5}{|c|}{$\begin{array}{l}\text { After the pandemic, do you use communal sites (camellia, } \\
\text { sports equipment, bench, WC etc.)? }\end{array}$} \\
\hline & & Definitely no & no & undecided & yes & Total \\
\hline Before the pandemic, did & Definitely no & $33.3 \%$ & $66.7 \%$ & & & $100.0 \%$ \\
\hline you use to use communal & No & $25.0 \%$ & $41.7 \%$ & $25.0 \%$ & $8.3 \%$ & $100.0 \%$ \\
\hline sites (camellia, sports & Undecided & $16.7 \%$ & & $50.0 \%$ & $33.3 \%$ & $100.0 \%$ \\
\hline equipment, bench, WC etc) & Yes & $5.8 \%$ & $34.8 \%$ & $7.2 \%$ & $52.2 \%$ & $100.0 \%$ \\
\hline & Definitely yes & & & & $100.0 \%$ & $100.0 \%$ \\
\hline Pearson Chi-Square & $\begin{array}{c}\text { Value } \\
29.586^{\mathrm{a}}\end{array}$ & $\begin{array}{l}\mathrm{df} \\
12\end{array}$ & & $\begin{array}{r}0.0 \\
0.10\end{array}$ & ance $(2-s$ & \\
\hline
\end{tabular}


$\mathrm{H}_{0}=$ Pandemic; Not changed the number of visitors to Çubuk-1 Dam.

$\mathrm{H}_{1}=$ Pandemic; Changed the number of visitors to Çubuk-1 Dam.

A significant difference by $\alpha=0.05$ was measured between visiting Çubuk-1 Dam and pandemic situation.

Thus $\mathrm{H}_{0}$ hypothesis is rejected. It is detected that during pandemic, tendency among people to visit Çubuk1 Dam Recreation Site went up.
It is detected that after the pandemic, Recreation Site's level of use fell nearly by half. Many of the non-users explained their lack of use as their inconfidence towards society thus their doubt regarding full compliance of others with the rules of pandemic situation.

Upon renewing safety measures it is detected that visitors' safety anxiety was affected positively. As safety equipments before and after the pandemic are analyzed it is realized increase in the number of safety staff boosted feeling of trust among visitors.

Table 8 . Visitors' level of safety anxiety before and after the renovation was measured

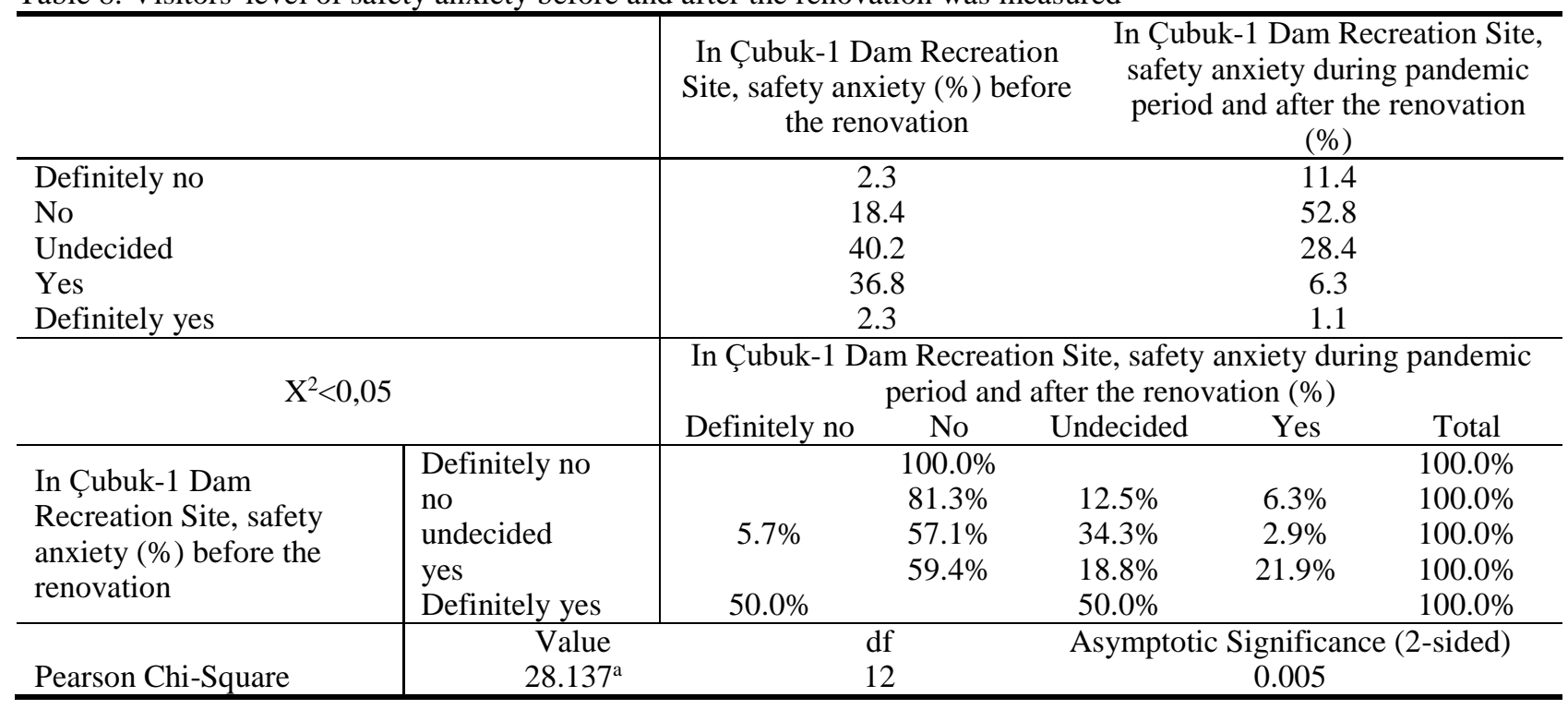

Table 9. Popular activity trends of participants before and after the pandemic

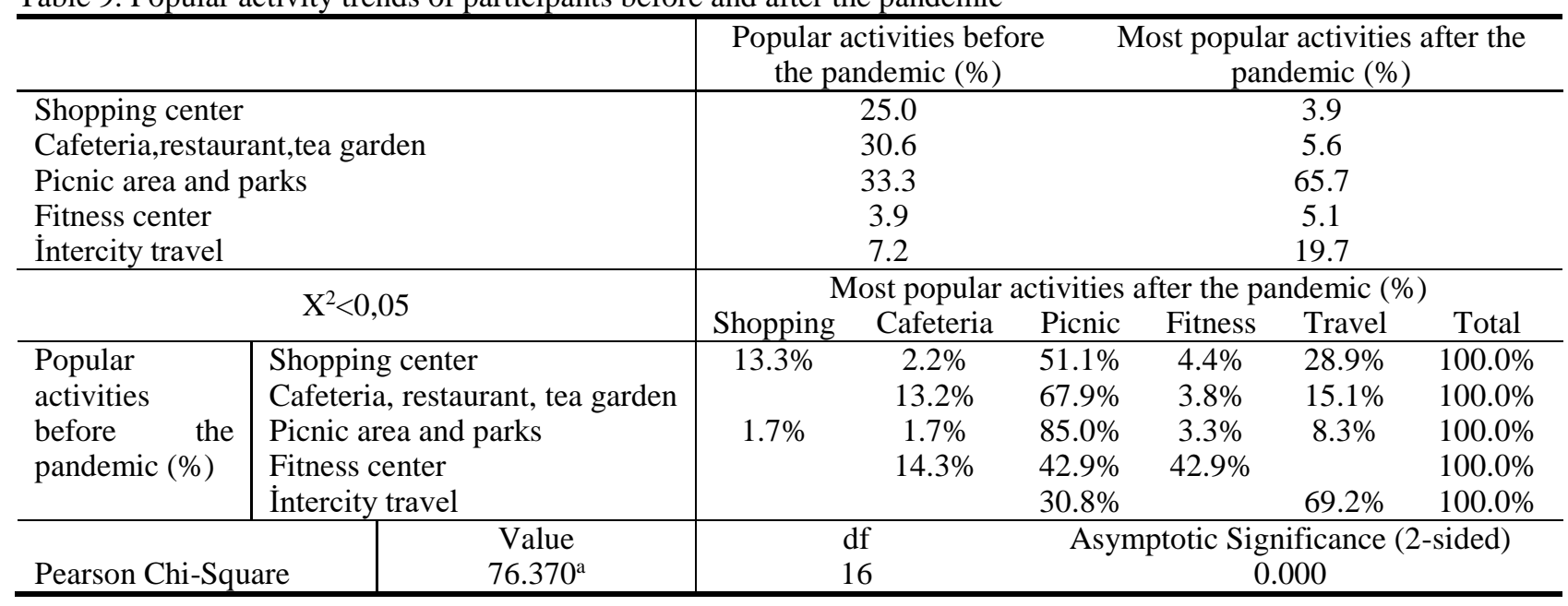

It was detected that those who mostly visited malls or cafes, restaurants and teashops before the pandemic oriented mostly towards picnic sites after the pandemic. Indeed, responses to the question related to increased interest for green spaces after the pandemic are supportive of this deduction since around $96 \%$ of visitors responded positively to this question. In their visits, participants reported to get psychological and physical relief by a ratio of $99 \%$. In the same vein participants' responses signaled that after the pandemic Çubuk-1 Dam recreation site became more crowded hence after the pandemic, there would be need for more numbers of green spaces.
Question about getting psychological and physical relief in Çubuk-1 Dam recreation site visit after pandemic was mostly answered positively and percentage distribution is as given in Table 10.

Question related to participants' opinion about the efficiency of Çubuk-1 Dam recreation site after its renovation during pandemic period was mostly responded positively. Those who deemed it insufficient listed their expectations as more numbers of activity areas, increased numbers of sitting units and more attention on hygiene due to pandemic situation. Based on these responses it can be stated that participants emphasized that during this period 
people demanded to spend more time in open green spaces that allow social distancing via functional sitting units and thus can socialize more.

Table 10. Distribution related to Çubuk-1 Dam Recreation participants' psychological and physical wellbeing in Çubuk-1 Dam recreation site.

\begin{tabular}{l|cc}
\hline \multicolumn{1}{c|}{ Sigh of relief } & $\mathrm{N}$ & $\%$ \\
\hline Definitely no & 1 & 0.6 \\
No & 2 & 1.1 \\
Undecided & 26 & 14.8 \\
Yes & 84 & 47.7 \\
Definitely yes & 63 & 35.8 \\
Total & 176 & 100 \\
\hline
\end{tabular}

Table 11. Distribution related to general users' abidance by the rules in pandemic Çubuk-1 Dam Recreation Site.

\begin{tabular}{l|cc}
\hline & Frequency & Valid Percent \\
\hline Definitely yes & 9 & 5.1 \\
Yes & 50 & 28.6 \\
Undecided & 88 & 50.3 \\
No & 20 & 11.4 \\
Definitely no & 8 & 4.6 \\
Total & 175 & 100.0 \\
\hline
\end{tabular}

Table 12. Distribution of the responses for the question related to the views on using of social distanced urban furniture after pandemic:

\begin{tabular}{l|cc}
\hline & Frequency & Valid Percent \\
\hline Totally enough & 17 & 9.4 \\
Partially enough & 84 & 46.7 \\
Undecided & 38 & 21.1 \\
Not enough & 25 & 13.9 \\
Not enough at all & 16 & 8.9 \\
Total & 180 & 100.0 \\
\hline
\end{tabular}

Table 13. Distribution related to believing that after the pandemic humans' lifestyles have changed (hygiene, distance, empathy, respect etc.):

\begin{tabular}{l|cc}
\hline \multicolumn{1}{c|}{ Situation } & N & $\%$ \\
\hline Definitely No & 5 & 2.8 \\
No & 10 & 5.6 \\
Undecided & 32 & 18 \\
Yes & 98 & 55.1 \\
Definitely Yes & 33 & 18.5 \\
\hline Total & 178 & 100 \\
\hline
\end{tabular}

Table 14. Distribution related to the question of the kind of solution applied if there is concern for personal hygiene when using urban furniture:

\begin{tabular}{l|cc}
\hline \multicolumn{1}{c|}{ Solution types } & $\mathrm{N}$ & $\%$ \\
\hline I wipe with a wet wipe/towel & 10 & 5.6 \\
I disinfect by squeezing & 69 & 38.8 \\
disinfectant/cologne & & \\
I use it carefully and then disinfect & 66 & 37.1 \\
myself & 25 & 14 \\
I don't use street furniture & 8 & 4.5 \\
I am not worried when using street & 178 & 100 \\
furniture & \\
Total &
\end{tabular}

When asked about their belief if or not other visitors abided by pandemic rules, participants failed to give a decisive response and in general it is realized that despite observing personally, they always felt somehow suspicious and as a result every participant paid attention to their personal hygiene at most and took great care on individual measures.

With a mean value by 3,34, participants in unstable setting disperse via 0,87 standard deviation. Before the pandemic too, Çubuk-1 Dam recreation site visitors' tendency to use social distanced urban furniture before and after the pandemic was aimed to be measured and evaluated within $\alpha=0,05$ significance level and it became apparent that compared to pre-pandemic period, equipment use ratios of visitors went down.

The majority of those believing that after pandemic humans' lifestyles did not change (hygiene, distance, empathy, respect etc.) stated that social distance had not been protected.

After the pandemic many of the participants stated that social distanced urban furniture use was adequate and after the pandemic too, they would continue using social distanced urban furniture.

\section{Conclusion}

The aim of this study was to seek answers for the question if or not a change occurred in the attitudes and behaviors of users before and after the pandemic. The study was built upon Çubuk-1 Dam recreation site and collected responses from the participants evidenced that participants relieved the stress due to lockdown measures by visiting recreation sites which became more popular compared to pre- pandemic stage.

It became apparent once more that during pandemic situation, for socializing, fresh air, activity zones offering a chance for physical mobility, attain spiritual comfort citizens needed green spaces with water surfaces and also green areas. Changes in lifestyle can be taken as a sign of promoting the use of social distanced urban furniture so as to satisfy the need for socializing and a proof for getting more used to living with pandemic. Participants reported that from then on they would spend their free time in recreation sites thus validating the importance of recreation sites in cities.

\section{References}

Abrams D, Lalot F, Hogg MA. 2021. Intergroup and intragroup dimensions of Covid-19: A social identity perspective on social fragmentation and unity. Group Processes \& Intergroup Relations, 24 (2), 201-209.

Ahmadpoor N, Shahab S. 2021. Realising the value of greenspace: a planners' perspective on the Covid-19 pandemic. Town Planning Review, 92 (1), 49-56.

Anonim, 2020. Çin'de Covid-19 pandemisi. Alındığı web sitesi: https://tr.wikipedia.org/wiki/\%C3\%87in\%27de_COVID19_pandemisi (Erişim 15.11.2020)

Anonim, 2020b. COVID-19 Strategic Preparedness and Response Plan Operational Planning Guideline, 1 February 2021 to 31 January 2022. World Health Organization. https://apps.who.int/iris/handle/10665/340073. License: CC BY-NC-SA 3.0 IGO (Erişim 15.11.2020) 
Anonim, 2020c. Koronavirüs tehlikesi kentlerde daha yüksek. Web adresi: https://www.dw.com/tr/koronavir\%C3\%BCstehlikesi-kentlerde-daha-y\%C3\%BCksek/a-54343087 (Erişim: 15/11/2021)

Anonim, 2021. COVID-19 Bilgilendirme Platformu. T.C. Sağl1k Bakanlığ1 Covid-19 Bilgilendirme Sayfas1. https://covid19.saglik.gov.tr/?gclid=earaiqobchmır7vkttpp7g 1vbdych0uoggveaayasaaegıulpd_bwe (Erişim 15.11.2020)

Bayramoğlu E, Yurdakul NM. 2020. Trabzon 100. Y1l Parkı ve Çevresinin Rekreasyon Potansiyelinin Saptanması. Bartın Orman Fakültesi Dergisi, 22 (1), 38-46. DOI: 10.24011/ barofd.621911

Chen C, Luo W, Li H, Zhang D, Kang N, Yang X, Xia Y. 2020. Impact of perception of green space for health promotion on willingness to use parks and actual use among young urban residents. International journal of environmental research and public health, 17 (15), 5560.

Coşku E, Koçyiğit M. 2020. Kent İmajının ve Kentsel Rekreasyon Alanlarına Yönelik Algının Ölçümü. Aksaray İletişim Dergisi, 2 (1), 66-81.

Düzenli T, Alpak EM. 2017. Yaşlıların Kentsel Açık Mekân Kullanımlarının İncelenmesi: Trabzon Kenti Örneği. Yaşlı Sorunları Araştırma Dergisi, 10 (2), 1-8.

Erdoğanaras F, Camur KC, Tamer NG, Mercan K. 2020. Covid19, Mahalle, Müşterekler, Kentsel Yaşam ve Halk Sağlığı. Türk Coğrafya Dergisi (76), 115-128. DOI: $10.17211 /$ tcd. 816835 .

Eryılmaz G, Kamil U. 2019. Açık Alan Rekreasyon Etkinliklerine Katılan Bireylerin Pozitif ve Negatif Duygu Durumlarının Karşılaştırılması. Gastroia: Journal of Gastronomy And Travel Research, 3(4), 562-578.

Gascon M, Triguero-Mas M, Martínez D, Dadvand P, Forns J, Plasència A, Nieuwenhuijsen MJ. 2015. Mental health benefits of long-term exposure to residential green and blue spaces: a systematic review. International journal of environmental research and public health, 12(4), 4354-4379.

Güngör S. 2019. Yaşlı Bireyler Açısından Peyzaj Tasarımının Konya Japon Park1 Örneğinde İncelenmesi. Yüzüncü Y1l Üniversitesi Tarım Bilimleri Dergisi, 29, 54-62. DOI: 10.29133/yyutbd.475409
Karlı RGÖ, Çelikyay S. 2020. Akıllı Kentlerin Gelişiminde Covid-19 Etkisi. Yüzüncü Y1l Üniversitesi Sosyal Bilimler Enstitüsü Dergisi (Salgın Hastalıklar Özel Sayıs1), 321-338.

Kılıç CH, Güdük Ö. 2018. Yeşil Hastane Kavramı ve Türkiye'deki Son Kullanıcıların Beklentileri Üzerine Bir Hastane Örneği. Gümüşhane Üniversitesi Sağlık Bilimleri Dergisi, 7(1), 164-174.

Lopez B, Kennedy C, McPhearson T. 2020. Parks are Critical Urban Infrastructure: Perception and Use of Urban Green Spaces in NYC During COVID-19. Preprints 2020, 2020080620 (doi: 10.20944/preprints202008.0620.v1).

Loureiro A, Veloso TJ. 2014. Outdoor exercise, well-being and connectedness to nature. Psico, 45(3), 299-304.

Özcü AE, Atanur G. 2020. Covid-19 Pandemisinin Kent Yaşamına Etkisi: Kamusal Alan Üzerine Değerlendirmeler. Paradoks Ekonomi Sosyoloji ve Politika Dergisi, 16(2), 237250.

Özgen Y, Büyüktolu R. 2016. Cumhuriyetin ilk barajı: Çubuk Baraj1 (1929-1936). Atatürk Yolu Dergisi. Cilt 15, Say1 59. Sayfa:87-110.

Polat AT, Güngör S, Akay A. 2018. Kent Park1 ve Tema Park1 Kavramlarının Konya İli Örneğinde İrdelenmesi. Kent Park1 ve Tema Parkı Kavramlarının Konya İli Örneğinde İrdelenmesi. Kent Yönetiminde Yeni Yaklaşımlar ve Etkin Belediyecilik Uygulamaları. Sayfa: 308-323, Nobel. Yayın No.: 2202 ISBN: 978-605-7895-11-0

Savucu Y, Yücel AS. 2021. Covid-19 Küresel Salgını Döneminde Çocuklarda ve Ergenlerde Fiziksel Aktivitelerin Önemi Spor ve Sağlık Bilimlere Multidisipliner Bakış. Sayfa: 79-99. Güven Plus Grup A.Ş. Yayınları. 79-99. E-ISBN: 978-6057594-53-2

Tunçay H, Eşbah H. 2020. Sağlıklı Kentler ve Pandemi: Covid19 Pandemisinin Düşündürdükleri. PEYZAJ, 2 (2), 57-64. Retrieved from: https://dergipark.org.tr/tr/pub/peyzaj/issue/58728/839722

Yasin Ç. 2020. Covid-19 Süreci ve Kentsel Mekanların Kullanımının Yeniden Planlanması. Osmaniye Korkut Ata Üniversitesi İktisadi ve İdari Bilimler Fakültesi Dergisi, 4(2), 67-79. 